\title{
Screening of Bacillus Spp. Isolated From Amazon Basin As Potential Antagonist of Toxigenic Fusarium Graminearum
}

\author{
Flávio Fonseca Veras (I), Ana Paula Folmer Correa (I), Maievi \\ Fonini (I), Tiago Centeno Einloft (I), Juliane Elisa Welke (I), Adriano \\ Brandelli (I) \\ (I) ICTA/UFRGS - Instituto de Ciência e Tecnologia de Alimentos/ UFRGS (Av. Bento \\ Gonçalves n. 9500, Porto Alegre - RS, Brasil)
}

\section{Resumo}

Fusarium graminearum is a potential producer of several mycotoxins, as trichothecenes, causing economic and nutritional losses and risks to human and animal health. Researches about antagonistic potential microorganisms have increasead in order to control of fungal growth and mycotoxin synthesis. Bacillus strains isolated from aquatic environment of Brazilian Amazon basin have shown antifungal activity against filamentous fungi. There is no specific report on the impact of these isolates on growth of toxigenic F. graminearum. The aim of this work was to screen Bacillus strains isolated from aquatic environments of Brazilian Amazon region for their antifungal activity against mycelial growth of $\mathrm{F}$. graminearum. Both Bacillus strains and F. graminearum were obtained from the collection center at Laboratory of Applied Biochemistry and Microbiology (ICTA/ UFRGS, Brazil). For antifungal activity, bacteria were cultured in tryptone soy broth (TSB) for $48 \mathrm{~h}$ at $37^{\circ} \mathrm{C}$. Sterile molten potato dextrose agar (PDA) containing spore suspension was transferred to Petri dishes. After solidification, each isolate was inoculated on PDA plates. The inhibition zones were measured after 7 days of incubation at $25{ }^{\circ} \mathrm{C}$. To evaluate the effect on radial growth, Bacillus strains inocula were added on PDA, and a spore suspension was placed in the centre of each plates and incubated at $25{ }^{\circ} \mathrm{C}$ for 10 days. The growing radius of the fungal colonies was measured

\footnotetext{
Referência:

Flávio Fonseca Veras, Ana Paula Folmer Correa, Maievi Fonini, Tiago Centeno Einloft, Juliane Elisa Welke, Adriano Brandelli.Screening of Bacillus Spp. Isolated From Amazon Basin As Potential Antagonist of Toxigenic Fusarium Graminearum. In: Anais do 12 Congresso Latinoamericano de Microbiologia e Higiene de Alimentos - MICROAL 2014 [= Blucher Food Science Proceedings, num.1, vol.1]. São Paulo: Editora Blucher, 2014.

DOI 10.5151/foodsci-microal-044
} 
along two perpendicular diagonals and compared with control cultures. Radial growth rate was calculated by linear regression. Experiments were carried out with three separate replicate. All bacterial isolates showed antifungal activity with inhibition zones ranging from 5 to $10 \mathrm{~mm}$. In particular, Bacillus sp. P51 had better results showing an $80.4 \%$ reduction of colony growth, absence of spore formation and decreasing radial growth rate $(0.21 \mathrm{~mm} /$ day $)$. B. subtilis ATCC19659 was also tested as reference, has observed no antifungal activity. In control experiment, F. graminearum (without Bacillus inoculation) showed high growth rate $(3.20 \mathrm{~mm} /$ day). The genus Bacillus isolated from the Amazon region have potential to control the growth of toxigenic F. graminearum. Research is continuing to investigate antifungal compounds possible produced by these bacteria strains.

Palavras-Chave: Biocontrol, Bacillus species, mycotoxins, trichothecenes Agência de Fomento: CAPES 